\title{
МІЖНАРОДНЕ ВІЙСЬКОВЕ СПІВРОБІТНИЦТВО УКРАЇНИ: ІСТОРИКО-ТЕОРЕТИЧНИЙ АСПЕКТ
}

У статті розглядається історія виникнення, становлення та розвитку міжнародного військового співробітництва України. Проводиться огляд наукових розробок 3 питань міжнародного військового співробітництва. Розкривається соціологічна основа предмета та сутність міжнародного військового співробітництва в системі міжнародних відносин. Окрема увага приділяеться сучасному міжнародному військовому співробітництву з огляду на 25-річний історичний досвід.

Ключові слова: Міжнародне військове співробітництво України, військове співробітництво, держави-члени НАТО, Збройні Сили України, спільні цінності.

Актуальність дослідження. Сьогодні для протидії збройній агресії в умовах мілітаризації Російської Федерації одним з актуальних напрямів забезпечення воєнної безпеки України є: едективне використання двостороннього та багатостороннього співробітництва 3 партнерами i союзниками у військовій сфрері; впровадження стандартів i принципів держав-членів НАТО; залучення Збройних Сил України до міжнародних операцій НАТО та ЄС.

Разом 3 тим, відповідно до вимог Концепції редормування сектора безпеки та оборони України виникає потреба дослідити історико-теоретичні витоки міжнародного військового співробітництва України та встановити передумови його зародження та формування, сутність міжнародного співробітництва в системі міжнародних відносин, а також підсумувати історичний досвід 3 метою подальшого обгрунтування пропозицій щодо підвищення ефективності реалізації співробітництва 3 країнами-партнерами та союзниками [1, с. 12].

Лухтан Анатолій Іванович, здобувач кафедри правового забезпечення, Національний університет оборони України імені Івана Черняховського, м. Київ.

(C) Лухтан A.I., 2017 
Аналіз джерел $і$ літератури. Питання міжнародного військового співробітництва України розглядало широке коло наукових та науково-методичних робіт вітчизняних фрахівців: І. Авдошин, А. Войціховський, С. Галака, Є. Годованик, Л. Зіняк, С. Кубієвич, О. Мананчинський, О. Мещеряков, Г. Перепилиця, О. Погібко, I. Поліщук, М. Цурюпа, І. Храбан, С. Ліпкевич, І. Сліденко, О. Сивак, Б. Якимович та інші.

Серед інших заслуговуе на увагу робота Б. Якимовича 3 історії будівництва Збройних Сил України, де автор висвітлюе короткий період військового співробітництва України, - весна 1992 - літо 1993 року, але обмежуеться лише переліком міжнародних військових контактів, не розкриваючи їх зміст і результати. При цьому він робить спробу первинної систематизації, узагальнення та періодизації будівництва і участі України у міжнародному військовому співробітництві [2, с. 25].

У науковій праці з ціеї проблематики Авдошин I.B. пропонуе провести класифікацію основних понять «оборонне співробітництво», «військове співробітництво», «військово-технічне співробітництво» та інші [3, с. 220-226].

У свою чергу, Л. Зіняк у науковій праці «Міжнародноправові засади військового співробітництва України» відображае сутність міжнародно-правових засад міжнародного військового співробітництва. Він запропонував власне визначення терміну «міжнародно-правове військове співробітництво України» та дослідив: поняття, види і принципи співробітництва; генези його правової регламентації; особливості імплементації міжнародноправових норм у вітчизняне законодавство з урахуванням міжнародно-правових зобов'язань у військовій сфері, а також специфіки участі України в міжнародних інституціях військового співробітництва. Разом з тим, він зазначив, що міжнародне військове співробітництво ЗС України е одним із найбільш пріоритетних з огляду на необхідність підтримання миру $\mathrm{i}$ безпеки, як на національному, так і міжнародному рівні. Важко не 
погодитись 3 його думкою про те, що сприяючи стабільності та передбачуваності відносин між державами у військовій сфрері, міжнародне військове співробітництво створює підгрунтя для розвитку інших напрямів міжнародної співпраці [4, с. 3-11].

Досить грунтовно питання партнерства між Україною і НАТО, у тому числі в рамках конщорціума «Партнерство заради миру», розглядалося у працях В. Бержікова, В. Бурдяк, В. Бондарекна, В. Вороненка, В. Вагапова, В. Коряк, О. Крамаревського, С. Ліпкєвич, Є. Лісицина, Ю. Недзельського, К. Морозова, І. Тодорова, С. Речича, Б. Пархонського, Ю. Скалецького, О. Соскіна, В. Тертичного, В. Торбіна, О. Чалого та інших. У цих наукових працях приділяеться увага діяльності органів виконавчої влади України 3 питань забезпечення національної безпеки України, інтеграції її до систем европейської й євроатлантичної безпеки.

Водночас, у праці О.А. Делінського «Європейська система безпеки: міжнародно-правові аспекти становлення i розвитку» серед інших проблем частково приділяеться увага організаційно-правовим фрормам співпраці України 3 міжнародною міжурядовою організацією НАТО у сфрері побудови сучасної системи европейської безпеки, а також взаємовідносини України з ЄC у сдері зовнішньої політики, безпеки, військової і військово-технічної співпраці [5, с. 4].

У науковій роботі С. Речича «Воєнно-політичне співробітництво ЗС України (1991-2009рр.)» на основі грунтованого аналізу різнопланових джерел вперше узагальнено досвід воєнно-політичного співробітництва ЗС України з НАТО за 1991-2009 роки. У дослідженні, окрім іншого, він надав ощінку результатам співробітництва; військове-політичне співробітництво було розглянуто як система, елементами якої виступають нормативно-правова база, структура органів, відповідальних за співробітництво та механізм співробітництва, який включав інструментарій, програми (плани) співробітництва; встановлено 
послідовність розвитку, вдосконалення, взаємозв'язки основних елементів та систем військово-політичного співробітництва у цілому [6, с. 3].

Деякі питання участі 3С України у програмі «Партнерство заради миру» досліджено в науковій праці Ю. Недзельського. Зокрема, автором вперше: розкрито процес приєднання України до програми «Партнерство заради миру»; запропоновано періодизацію участі 3С України в програмі «Партнерство заради миру»; узагальнено результати розвитку оперативних можливостей визначених сил і засобів ЗС України; проаналізовано вплив фракторів на участь ЗС України в програмі «Партнерство заради миру»; висвітлено напрями, за якими здійснювалась участь ЗС України в програмі «Партнерство заради миру» та удосконалено алгоритм планування Цілей партнерства для ЗС України (на теоретичному рівні) [7, с. 3].

Окремий інтерес має наукова праця Д. Велігодського і Є. Мальцевої, в якій досліджуються основні документи нормативно-правової бази, якими регулювалося співробітництво між Україною і НАТО протягом 1991-2004 років у військовій та оборонно-промисловій сферах [8, с. 13].

Узагальненню та провадженню досвіду міжнародної миротворчої діяльності України приділялась увага таких вітчизняних дослідників, як: О. Бодрук, В. Леонов, Г. Перепелиця, І. Поліщук, В. Смолянюк, М. Цюрупа, Г. Хоменко. Одночасно вивченню нормативно-правової основи, ресурсного i організаційного забезпечення українських миротворців у міжнародних місіях присвячені праці: О. Губаренка, Є. Зозулі, О. Мещерякова, В. Нікітюка, В. Собкова, Г. Шелест та інших. У своїх наукових працях А. Войціховський, Г. Гозуватенко, Л. Голопатюк, В. Горбулін, В. Дронговський, В. Заросило, А. Лега, Н. Костенко, А. Мартинов, О. Мельник, О. Мещеряков, Н. Нижник, Т. Силіна, Г. Ситник та інші науковці розглядають питання участі України в міжнародних миротворчих операціях відповідно до мандатів Ради 
Безпеки ООН, а саме: досвід участі національних контингентів (персоналу) в миротворчих операщіях; правове регулювання діяльності миротворчих контингентів тощо.

Вітчизняні науковці-адміністративісти: В. Заросило, M. Курко, М. Міхеєв, О. Теличко, В. Венгер та інші надавали багато уваги питанню участі національних контингентів (персоналу) в миротворчих операціях. Інтерес також становлять публікації керівників Міністерства оборони України 3 питань застосування національних контингентів (персоналу) в миротворчих операціях на території іноземних держав: В. Гудима, О. Затинайка, С. Кириченко, О. Кузьмука, М. Пальчука, В. Собкова, В. Радецького, В. Шкідченка.

Частково питання участі 3С України у верифрікаційній діяльності, контролю над роззброєнням були висвітлені у працях I. Федотова, А. Лойшина та інших.

Таким чином, огляд науково-інформаційної бази 3 питань міжнародного військового співробітництва України свідчить про значний інтерес серед дослідників і науковців до вивчення цієї сфрери зовнішньополітичної діяльності держави. Проте історико-теоретичні питання міжнародного військового співробітництва України не були достатньо вивчені.

Метою статmi $є$ висвітити історико-теоретичні ознаки поняття "міжнародне військове співробітництво», його сутність і місце в системі міжнародних відносин у сучасних умовах; проаналізувати стан реалізації міжнародного військового співробітництва України у період з 1991-2011 рр. та 2013-2015 рр. відповідно.

Виклад основного матеріалу дослідження. Історичні джерела вказують, що виникнення, становлення i розвиток військового співробітництва відбувається у тісному взаємозв'язку 3 розвитком державно-правових систем. Так на сучасній території України перша згадка про військове співробітництво є у договорі Русі і Візантії 911, 945, 971 років. Відповідно до цих згадувань князь Ігор уклав договір 945 р. після невдалого походу на 
Візантію, де в статтях зазначено зобов'язання князя надавати грекам військову допомогу [9, с. 251].

У період другої половини XIV-XVII ст. військове співробітництво Великого князівства Литовського, Руського і Жемайтійського характеризується виявом пошуку надійних союзників для організації опору від зазіхань сусідніх держав. Так Велике князівство спільно 3 Королівством Польським протистояло: тиску Тевтонському ордену на північному заході; Московському князівству - на сході; набігам кримських татар - на півдні [10, с. 47].

У XVI ст. Запорозька Січ сформувала та підтримувала тісні контакти з Туреччиною, Угорщиною, Австрією, Московським царством, таким чином Запорозька Січ набула ознак суб'єкта міжнародного права [11, с. 147].

У період багатолітньої боротьби українського народу за визволення від польського гніту і створення власної держави можна зазначити наступні особливі риси військового співробітництва, як: створення інституцій зовнішніх зносин, для розробки та ухвалення статей численних договорів, трактатів із сусідніми країнами (це належало до повноважень Генеральної ради та Старшинської ради); укладання угод про військові союзи (Раднотський договір 1656 р. між Б. Хмельницьким та Швецією, Трансільванією, Бранденбургом про військовий союз для боротьби з Річчю Посполітою); домовленості про військову (збройну) підтримку (від кримського хана ІсламГірея III, яку згодом він порушив); акредитація послів та розвиток власних дипломатичних представництв (Туреччина, Швеція, Польща, Молдова).

У XX ст. укладання міжнародних договорів про військову (збройну) допомогу: за Брестським мирним договорол 27 січня 1918 . Українську Народну Республіку визнали Німеччина, Австро-Угорщина, Болгарія і Туреччина як суб’єкт міжнародного права, а це дало можливість отримати від них військову (збройну) допомогу для боротьби 3 більшовиками; Варшавський договір $21 \quad i \quad 24$ квітня 1920 . між Директорією 
(С. Петлюра) та Польщею (С. Пілсудський) дав можливість об’єднати українсько-польські війська у боротьбі проти більшовиків [10, с. 247-248; 11, с. 47].

Одне із найважливіших досягнень Вестфальського миру - фрормування основи правових відносин між державами Свропи. Це стало підгрунтям для започаткування та розвитку міжнародного військового співробітництва між збройними силами у зв'язку із закінченням релігійних воєн і встановленням Вестфальського миру. Цей процес започаткування і формування міжнародних відносин не тільки дало імпульс міждержавному правовому співробітництву країн Свропи, але визначило його основну спрямованість подальшого розвитку. На той час вихідними пунктами співробітництва держав як нових політичних одиниць стає взаємна повага суверенітету, невтручання у внутрішні справи один одного, а його основними цілями - свідоме прагнення урядів до подальшого закріплення національної безпеки i незалежності. Це створило умови для становлення, інституалізації i подальшого розвитку міжнародного військового співробітництва. Варто зазначити, що історичні етапи розвитку суспільства дали поштовх до збільшення кола суб'єктів міжнародного права. Сьогодні до них належать держави й державоподібні утворення, міжнародні міжурядові й неурядові організації, транснаціональні корпорації, суспільно-політичні рухи, які охоплюють населення двох і більше держав, нації, які борються за державність, тощо.

Як срормулював науковець П.А. Циганков, між народні відносини - це та частина соціальних відносин, яка перетинає межі державних кордонів [12, с. 51]. Він акцентує, що це процес взаємодії двох або кількох акторів, у якому немає місця застосуванню збройної сили i домінують пошуки спільних інтересів. Більш ширше визначення робить ЖЖ.П. Деррієнник, зокрема, він зазначає: "..два актори (суб'єкти) знаходяться у стані співробітництва, коли кожний із них ложе бути 
задоволений тільки в толу випадку, якщо задоволений й інший, тобто, коли кожний із них може дологтися досягнення своєї мети тільки тоді, коли иього може дологтися й інший. Результатол чисто кооперативного відношення може бути ситуація, у котрій або обидва актори задоволені, або не задоволений жодний із них ...” [13, c. 24].

Зазначаючи значні успіхи, досягнуті наприкінці XX століття в теоретичному дослідженні міжнародного співробітництва, науковці виділяють наступні досягнення у теорії визначення категорійно-понятійного апарату. Так американський політолог Р. Кеохейн та більшість вчених розуміють «співробітництво» як ситуацію, коли одні суб'єкти регулюють свою поведінку у відповідності 3 фрактичними або очікуваними перевагами інших, через процеси взаємної координацї політик. Іншими словами, міжнародне співробітництво передбачає наявність трьох елементів: а) спільні иілі суб'єктів; б) очікування нили вигоди від ситуаиї; в) взаєлний характер иієї вигоди. Він зазначає (Р. Кеохейн), що «..ккжний суб'єкт не обов'язково допомагає іншому, але якщо він робить це, то очікує покращення своєї власної ситуації, що приводить до взаємної координації державних політик...» [14, с. 36].

Можливо зробити висновок, що, по-перше, це дозволяє не просто знайти межі між співробітництвом i суперництвом (або конфліктом), а межі, в рамках яких проводиться діяльність 3 метою зменшення вигоди для інших або ж діяльність, спрямована на недопущення виконання їх інтересів.

По-друге, таке розуміння поняття «співробітництва» дає можливість відрізняти співробітництво від не співробітництва, тобто від односторонньої поведінки, де суб'єкти не враховують наслідки своїх дій щодо інших, а також від бездіяльності, тобто від поведінки суб'єктів, яка не попереджує негативні наслідки для політики інших сторін.

Міжнародне співробітництво як процес, що характеризує взаємодію міжнародних акторів, у якому домінують 
спільні пошуки можливостей реалізації інтересів усіх защікавлених сторін, безперечно грунтуеться на наявності довіри у відносинах між партнерами. Традиційно, як свідчить практика, співпраця розгортається на двосторонніх і багатосторонніх засадах. Залежно від засобів реалізації (імплементації) співпраця передбачає кординацію зовнішньополітичної діяльності держав, яка може бути двох видів: а) дискретна; б) інституційна. Так дискретна координація (або співробітництво типу аdhoc) $є$ узгодженістю, яка досягається шляхом так званих дискретних (окремих) дій, коли в кожному конкретному випадку держави (інші суб'єкти міжнародного середовища) домовляються самостійно використовувати певні заходи, інструменти, методи для досягнення належної єдності дій у певній сфрері міжнародних відносин. Погодження дій, яке виробляеться на засадах міжнародного режиму, тобто 3 використанням певних усталених норм, правил, звичаїв та практики, фрункціональних структур, належить до інституиійної координацї.

Міжнародні режими створюються за ініціативою міжнародних суб'єктів, завдяки узгодженості і реалізації їх очікувань, сукупністю пов'язаних з певними проблемами міжнародних інститутів, які обумовлюються фундаментальними принципами, нормами і процедурами ухвалення рішень [15, с. 56].

До проблем сьогодення, щодо існування міжнародних режимів у рамках універсальних інституцій, можливо віднести: а) невирішеність питань у сдері міжнародного миру і безпеки, які вимагають об'єктивно переглянути та посилити інституційну координацію в міжнародних відносинах; б) фактори залежності від великої кількості учасників переговорного процесу, що ускладнює досягнення порозуміння між суб'єктами та викликає залежність учасників переговорів та урядових осіб від громадської думки в кожній державі тощо [16, с. 8].

Усвідомлення наявних проблем, у тому числі збереження міжнародного миру і безпеки в цілому, дозволяє 
сформувати ще один важливий елемент світосприйняття набір певних цінностей, які визначають мету створення відповідного міжнародного режиму. Наприклад, ООН, HATO, СС та низка інших міжнародних організацій визначають себе, передусім, як об'єднання держав на основі спільних цінностей. Водночас, такі цінності містяться у міжнародно-правових документах, проте їх джерелом може бути також міжнародний звичай чи навіть просто традиція [17, 18, 19].

Варто зазначити, що активну участь у формуванні міжнародних режимів та формальних об’єднань держав беруть міжурядові організації наділені спеціалізованою або універсальною компетенцією. Складаючись з окремих держав, вони одночасно виступають як колективні актори, що діють цілеспрямовано [10, с. 3-5]. Головна фуункція полягає у формулюванні спільних цілей країн-членів i визначенні засобів для їх досягнення. Як зазначає у науковій праці В.С. Бруз, вони відіграють роль своєрідних банків інформації 3 певних проблемних питань та сприяють створенню єдиних стандартів в окремих галузях міжнародного співробітництва [20, с. 6].

Розглядаючи міжнародне військове співробітництво України, доречно підкреслити те, що Україна реалізує національні інтереси з метою забезпечення національної безпеки, зокрема у військовій сфері, спираючись на норми та принципи міжнародного права, розвиває добросусідські відносини з усіма країнами, насамперед, із стратегічними партнерами, суміжними-країнами, міжнародними безпековими організаціями.

За 25-річний період будівництва та реформування сектора оборони Міністерством оборони України започатковано та здійснюеться міжнародне військове співробітництво з 89 оборонними відомствами країн світу. Серед них: з 55 країнами - на основі міжнародно-договірної бази, 334 країнами - за окремими домовленостями. Міжнародно-договірна основа співробітництва Міноборони складається 3382 міжнародно-договірних документів 3 
питань військового та військово-технічного співробітництва. В Україні акредитовано 44 апаратів аташе 3 питань оборони іноземних держав, з них 7 апаратів аташе за сумісництвом [21].

За період з 1991 по 2011 роки Україна виробила відповідну міжнародно-договірну основу та досягла вагомих здобутків у реалізації державної політики у військово-технічній срері. Так з 1993 по 2011 роки укладено 41 міжурядову двосторонню угоду 3 питань військово-технічного співробітництва 3 іноземними країнами [22]. Безперечно це надало підгрунтя для створення дієвого механізму співробітництва у сорері ВТC шляхом засідання міжурядових комісій 3 питань військово-технічного співробітництва та експортного контролю. За інформацією Міністерства економічного розвитку і торгівлі України, на кінець 2011 року було ссрормовано та діяло 24 міжурядових (спільних, міждержавних) комісій 3 питань військово-технічного співробітництва [23].

За період 31992 по 2014 рр. в українському законодавстві сорормовано системні підходи щодо участі в операціях 3 підтримки миру та безпеки (миротворчих операціях) під егідою ООН, НАТО, СС, ОБСС.

Різки зміни у воєнно-політичній обстановці навколо України 3 грудня 2013 року по лютий 2014 року скорегували зовнішньополітичний курс України та призвели до перегляду питання позаблокового статусу держави. Зміни до закону України «Про засади зовнішньої та внутрішньої політики» надали новий поштовх міжнародному військовому співробітництву України, серед основних це реалізації відносин партнерства й довіри у військовій сфрері, а також реалізації спільної політики безпеки i оборони СС; гідного сприйняття України на міжнародному рівні та належного виконання зобов'язань «країни-контрибутора» ООН; відповідність критеріям членства України в СС і НАТО; редормування ЗС України з метою досягнення оперативної і технічної сумісності зі ЗС держав-членів НАТО [21, с. 4]. 
В умовах продовження ескалації РФ конфлікту на Сході України і анексії АР Крим міжнародне військове співробітництво України використовуе дипломатичні важелі у воєнно-політичній сфері проведенням численних міжнародних консультацій і зустрічей, для привернення уваги світової спільноти до агресивної зовнішньої політики РФ, зростання військової присутності в Свропі та ігнорування фрундаментальних принципів міжнародного права щодо України, а також отримання консультативнодорадчої та матеріально-технічної допомоги від країнпартнерів.

В рамках імплементації воєнно-політичних цілей протягом 2015 року проведено 1078 заходів міжнародного співробітництва MO та ЗС України. Двосторонне військове співробітництво ЗС України активно реалізується 3 країнами-партнерами (США, Королівство Великої Британії та Північної Ірландії, Канада, Республіка Польща, Литовська Республіка, ФРН, Франція, інші). Відповідно до визначених пріоритетів у 2015 року проведено заходи за такими напрямами: а) активізація воєнно-політичного діалогу (проведення заходів на вищому рівні, воєнно-політичні консультації); б) отримання консультативно-дорадчої та матеріальнотехнічної допомоги для ЗС України; в) фрахова (профресійна) підготовка українських військовослужбовців; г) лікування (реабілітація) бійців, які постраждали під час ведення бойових дій на Сході України [25, с. 2]. У цьому контексті необхідно зазначити інтенсифікацію двостороннього співробітництва з такими державамипартнерами, як США, Канада, Велика Британія, ФРН та країнами Балтії. Зокрема, отримано значну матеріальнотехнічну (гуманітарну) допомогу та допомогу в лікуванні й реабілітації військовослужбовців, поранених під час ведення бойових дій в зоні АТО.

Основні зусилля в контексті багатостороннього військового співробітництва та співробітництва в рамках міжнародних організацій та ініціатив спрямовувалися на 
забезпечення інтеграції України в европейський політичний, економічний, правовий простір 3 метою набуття членства в СС, а також на поглиблення співпраці з НАТО 3 метою досягнення критеріїв, необхідних для набуття членства у цій організації.

Пріоритетні напрями військового співробітництва з ЄС були: а) розширення формату воєнно-політичного діалогу між керівництвом ЗС України та СС; б) підготовка до спільних військових навчань, а також багатонаціональних операцій 3 підтримання миру; в) залучення ЗС України до фрормування бойових тактичних груп $\mathrm{CC}$; г) підготовка представників 3С України з питань СПБО; д) співробітництво 3 країнами Східного партнерства 3 питань реалізації СПБО.

При виконанні заходів Річної національної програми 2015 Україна-НАТО основні зусилля спрямовувалися на: а) кардинальний перегляд конщептуальних документів стратегічного та оборонного планування із залученням експертної допомоги НАТО; б) нарощування оперативних спроможностей ЗС України; в) створення ССО ЗС України як окремого роду військ; г) удосконалення системи організації бойової підготовки ЗС України, проведення спільних навчань, тренувань та участь в операціях Альянсу; д) підвищення взаємосумісності ЗС України з військами Альянсу; е) інтенсифікацію військово-технічного співробітництва; ж) розвиток систем зв'язку та автоматизації ЗС України; з) рефрормування систем логістики і стандартизації ЗС України, розвиток можливостей військової медицини; i) забезпечення психологічної та фрізичної реабілітації військовослужбовців, постраждалих під час проведення Антитерористичної операції [25, с. 3].

Одним із основних механізмів досягнення необхідного рівня взаємосумісності з НАТО та критеріїв, необхідних для набуття членства в Організації Північноатлантичного договору, а також практичної реалізації військового співробітництва між ЗС України та Альянсу є Індивідуальна програма партнерства (далі - ІПП). У 2015 році в 
рамках ІПП 267 представників ЗС України взяли участь у 153 заходах військового співробітництва. Основні зусилля співробітництва ЗС України з НАТО в рамках ІПП між Україною та НАТО протягом 2015 року було зосереджено на пріоритетних напрямах: а) розвиток системи управління i зв'язку; б) розвиток сил спеціальних операцій; в) логістика та військова медицина; г) інформаційнопсихологічні операції; д) підготовки спеціалістів у галузі розмінування та протидії саморобним вибуховим пристроям; е) кіберзахист.

Висновки. За результатами дослідження можливо зазначити наступне:

поняття «міжнародне військове співробітництво» $\epsilon$ досить важливим у теорії міжнародних відносин, оскільки є визначальним питанням у взаємодії між державами i міжнародних організацій 3 метою досягнення спільних цілей у забезпеченні міжнародного миру і безпеки;

умовою розвитку міжнародного військового співробітництва є тривале і стабільне безкризове співіснування держав-партнерів, позаяк лише в такому разі можуть виникати близькі за змістом і навіть спільні інтереси, потреба у реалізацї яких визначае стан міжнародного миру і безпеки;

історичні джерела військового співробітництва на території сучасної України свідчать про наявність передумов розвитку між суміжними країнами відносин добросусідства та дотримання міжнародних принципів співробітництва, які закріплені в статуті ООН та інших міжнародних договорах;

25-річний досвід міжнародного військового співробітництва свідчить про те, що відбулися етапи зародження, формування та розвитку системи міжнародного військового співробітництва України, де визначальною складовою було i залишається забезпечення міжнародного миру і безпеки в регіоні та у світі в цілому;

сучасні виклики і загрози національним інтересам України визначають пріоритетне місце міжнародному 
військовому співробітництву, в системі забезпечення національної безпеки держави, а також встановлюють завдання 3 отримання підтримки міжнародного співтовариства для відновлення миру, захисту територіальної цілісності і суверенітету; вжиття заходів із консолідації міжнародних зусиль для забезпечення повернення РФ до цивілізованого поля міждержавних відносин;

в умовах наростаючої російської агресії (2014-2015рр.), ЗС України продовжували нарощувати свої оперативні спроможності завдяки проведенню заходів військового співробітництва зі збройними силами країн-партнерів: США, Канади, Великої Британії, ФРН, країн Балтії та в рамках партнерства з НАТО та ЄС.

1. Про рішення Ради національної безпеки і оборони України «Про концепцію розвитку сектору безпеки і оборони України: Указ Президента України [від 4 березня 2016 року] // Відомості Верховної Ради України. - 2016 р. - № 46. - 1477 с.

2. Якилович Б. Збройні Сили України: нарис історії/ Б. Якимович. - Львів, 1996. - С. 359.

3. Авдошин I.B. Правове регулювання міжнародного співробітництва України у військовій ссері // I.В. Авдошин : Стратегічна панорама. - № 2. 2008. - C. $220-226$.

4. Зіняк Л.В. Міжнародно-правові засади військового співробітництва України : автореф. дис.... канд. юрид. наук : [спец.] 12.00.11 «Міжнар. право» / Зіняк Любомир Васильович ; Нац. юрид. ун-т ім. Я. Мудрого. - Х., 2015. - С. 10-13.

5. Делінський О.А. Європейська система безпеки: міжнародно-правові аспекти становлення i розвитку : автореф. дис. ... канд. юрид. наук : [спец.] 12.00.11 «Міжнар. право» / Делінський Олександр Аркадійович ; Нац. юрид. акад. України ім. Я. Мудрого. - Х., 2003. - 12 с.

6. Речич С.Л. Военно-політичне співробітництво Збройних Сил України з НАТО (1991-2009рр.) : автореф. дис. ... канд. істор. наук : [спец.] 20.02.22 «Військова історія» / Речич Сергій Леонідович ; Нац. універ. оборони України. - К., 2012.

7. Недзельський Ю.О. Участь Збройних сил України в програмі «Партнерство заради миру» (1994-2010рр.) 
автореф. дис. ... канд. істор. наук : [спец.] 20.02.22 «Військова історія» / Недзельський Юрій Олексійович; Нац. універ. оборони України. - К., 2012.

8. Велігодський Д.В., Мальцева Є.В. Особливості нормативно-правового регулювання співробітництва України з НАТО в 1991-2004 роках // Д.В. Велігодський, С.В. Мальцева ; Ученые записки Таврийского национального университета им. В.И. Вернадского Серия «Юридические науки». том 22 (61). - № 2. - 2009. - С. 11-13.

9. Історія держави і права України: У 2 т./ за ред. В.Я. Тація. - К., 2000. - Т. 1.

10. Захарченко П.П. Історія держави і права України: підручник. - К.: Атіка, 2005. -368 с.

11. Кузьлинець О., Калиновський В. Історія держави та права України. - К., 2002.

12. Цыганков П.А. Международные отношения. M.,1996. - C.320.

13. Чекаленко Л.Д. Зовнішня політика України: підручник. - К.: Либідь, 2006. - 716 с.

14. Keohane R. International Institutions and State Power: Essays in International Relations Theory. Boulder; San-Francisco; London: Routledge, 1989. $250 \mathrm{p}$.

15. Циганкова T., Гордєєва T. Міжнародні організації: навч. посібник. - 2-ге вид., перероб. і доп. - К.: KHEУ, 2001. - C. 340.

16. Фролов С.С. Социология: Учебник для высших учебных заведений. -2 -е изд., перераб. и доп. - М.: Изд. корпорация «Логос», 1996. - С. 360.

17. Статут Організації Об'еднаних Націй i Статут Міжнародного Суду. ООН; Статут, Міжнародний документ від 26 червня 1945 року, Документ, чинний, остання версія - Редакція від 16.09.2005 [Електронний ресурс]. - Режим доступу: http://zakon2.rada.gov.ua/laws/show/995_010.

18. Північноатлантичний договір, Міжнародний документ від 04.04.1945 [Електронний ресурс]. Режим доступу: http://zakon4.rada.gov.ua/laws/ show/950_008.

19. Клаус-Дітер Боршарт Абетка законодавства Європейського співтовариства // Переклад з анг. К.: ТОВ «Вірксам», 2001. - С. 112. 
20. Спеціалізовані і установи системи ООН: навч. посібник / В.С. Бруз, В.М. Грабажей, В.О. Слфімов та ін; за ред. В.С. Бруза. - К.: Либідь, 1995. - С. 116.

21. Департамент міжнародного оборонного співробітництва Міністерства оборони України [Електронний ресурс]. - Режим доступу: http://www.mil.gov.ua/index.php?lang=ua\&part=depa rtment\&sub=dms.

22. Перелік міжнародних угод у сфері військовотехнічного співробітництва: Військово-технічне співробітництво / Міністерство економічного розвитку та торгівлі, офріційний сайт [Електронний peсурс]. - Режим доступу: http://www.me.gov.ua/ Documents/List?lang=uk-UA\&tag=ViiskovotekhnichneSpivrobitnitstvo.

23. Перелік Українських частин комісій 3 питань військово-технічного співробітництва, до складу яких включені представники Мінекономрозвитку: Військово-технічне співробітництво / Міністерство економічного розвитку та торгівлі, офіційний сайт [Електронний ресурс]. - Режим доступу: http://www.me.gov.ua/Documents/List?lang=ukUA\&tag=Viiskovo-tekhnichneSpivrobitnitstvo.

24. Про засади внутрішньої і зовнішньої політики : Закон України [від 1 липня 2010 року № 2411-VI : Із змінами, внесеними згідно із Законами № 1170-VII від 27.03.2014, BBP, 2014, № 22, ст. 816, № 35-VIII від 23.12.2014, BBP, 2015, № 4, ст. 13] // Відомості Верховної Ради України. - 2010 р. № $40 .-$ C. 1452 , стаття 527.

25. Основні зусилля МО України в сфері міжнародного військового співробітництва України у 2015 році (індормаційний матеріал): Міжнародне співробітництво: Міністерство оборони України [Електронний peсурс]. - Режим доступу: http://www.mil.gov.ua/ diyalnist/mizhnarodne-spivrobitnicztvo/. 
Надійшла до редколегії 16.12.2016 р.

Рецензент: О.П. Красюк, кандидат військових наук, доцент, заступник начальника Національної академії 3 навчальної роботи, Національна академія сухопутних військ імені гетьмана Петра Сагайдачного, м. Львів.

\section{Лухтан А.И. \\ МЕЖДУНАРОДНОЕ ВОЕННОЕ СОТРУДНИЧЕСТВО УКРАИНЫ: ИСТОРИКО-ТЕОРЕТИЧЕСКИЙ АСПЕКТ}

В статье рассматривается история возникновения, становления и развития международного военного сотрудничества Украины. Проводится обзор научных разработок по вопросам международного военного сотрудничества. Раскрывается социологическая основа предмета и сущность международного военного сотрудничества в системе международных отношений. Особое внимание уделяется современному международному военному сотрудничеству с учетом 25-летнего исторического опыта

Ключевые слова: Международное военное сотрудничество Украины, военное сотрудничество, государства-члены НАTO, Вооруженные Силы Украины, общие ценности.

\section{Luhtan A.}

INTERNATIONAL MILITARY COOPERATION OF UKRAINE: HISTORICAL AND THEORETICAL ASPECTS

The article deals with the origins, formation and development of Ukraine international military cooperation. A review of scientific developments on international military cooperation is conducting. Expands sociological basis of the subject and nature of international military cooperation in international relations. Special attention is paid to the modern international military cooperation with regard to twenty-five years of historical experience.

Keywords: International Military Cooperation of Ukraine military cooperation, NATO member states, the Armed Forces of Ukraine, shared values. 